\title{
Asterodiscus and Stigmatodiscus, two new apothecial dothideomycete genera and the new order Stigmatodiscales
}

\author{
Hermann Voglmayr ${ }^{1}$ - Alain Gardiennet ${ }^{2}$ • Walter M. Jaklitsch ${ }^{1,3}$ \\ Received: 25 August 2015 / Accepted: 11 January 2016 / Published online: 2 February 2016 \\ (C) The Author(s) 2016. This article is published with open access at Springerlink.com
}

\begin{abstract}
During a survey on corticolous Dothideomycetes, several collections with ascospores matching the genera Asteromassaria and Stigmatomassaria (Pleomassariaceae, Pleosporales) were revealed from dead corticated twigs of Acer, Carpinus and Tamarix. Closer morphological examination showed that their ascomata were apothecial, with a hamathecium consisting of septate, branched paraphyses, which are apically swollen at maturity. Several collections were cultured and sequenced, and a Blast search of their nuc 28S rDNA sequences revealed dothideomycetous affiliation, but without a close match to a specific family or order. Phylogenetic analyses of a multigene matrix containing a representative selection of Dothideomycetes from four genes (nuc 18S rDNA, nuc 28S rDNA, rpb2 and tef1) revealed placement within Dothideomycetes but without a supported familial or ordinal affiliation. Based on the phylogenetic analyses and morphological investigations, the new genera Asterodiscus and Stigmatodiscus, with the two new species A. tamaricis and $S$. enigmaticus, are described and illustrated, and placed in the new family Stigmatodiscaceae and new order Stigmatodiscales.
\end{abstract}

Hermann Voglmayr

hermann.voglmayr@univie.ac.at

1 Division of Systematic and Evolutionary Botany, Department of Botany and Biodiversity Research, University of Vienna, Rennweg 14, A-1030 Vienna, Austria

214 rue Roulette, F-21260 Véronnes, France

3 Institute of Forest Entomology, Forest Pathology and Forest Protection, Department of Forest and Soil Sciences, BOKU-University of Natural Resources and Life Sciences, Hasenauerstraße 38, A-1190 Vienna, Austria
Keywords Ascomycota - Dothideomycetes · New species · New genus $\cdot$ New family $\cdot$ New order $\cdot$ Phylogenetic analysis Taxonomy

\section{Introduction}

During a survey on corticolous ascomycetes in Istria, Croatia in September 2010, we collected a dothideomycetous species from dead corticated twigs of Carpinus orientalis which showed ascospores with a striking resemblance to Stigmatomassaria pupula (Pleomassariaceae, Pleosporales; see Barr 1982, under Splanchnonema pupula). They were first considered to represent poorly developed, aberrant ascomata of Stigmatomassaria, but detailed morphological examination showed that the ascomata were clearly apothecial, with ascomata opening at maturity and having septate paraphyses with apical swellings at their free ends. Sequence data obtained from cultures of ascospores left no doubt that they do not belong to Stigmatomassaria or even Pleosporales. NCBI Blast searches confirmed dothideomycetous affinities, but without indication of a closer relative. Subsequently, we collected and cultured the fungus several times from Acer monspessulanum, A. campestre and A. sempervirens from various European countries.

In summer 2013, we found another dothideomycetous species on corticated dead twigs of Tamarix spp. with ascospores matching the genus Asteromassaria (Pleomassariaceae, Pleosporales; see Barr 1982), but again with apothecial ascomata having apically swollen paraphyses. Sequence data obtained from pure cultures revealed a close phylogenetic relationship to the Stigmatomassaria-like apothecial dothideomycete.

These fungi could not be identified upon consultation of the taxonomic literature, and no genera or families offered 
themselves for an appropriate taxonomic placement. Therefore, they are described in the new genera Asterodiscus and Stigmatodiscus, which are placed in a new family and order within Dothideomycetes, according to the results of multigene phylogenetic analyses and detailed morphological investigations.

\section{Materials and methods}

\section{Morphological observations}

Hand sections of ascomata were made using a razor blade and mounted in water on a microscope slide, gently torn apart with a preparation needle when necessary and covered with a cover slip. Slides were examined and photographed using a Zeiss Axio Imager.A1 (Zeiss, Jena, Germany) microscope equipped with a Zeiss AxioCam ICc3 or Axiocam 506 colour digital camera. Measurements are reported as maxima and minima in parentheses and the mean plus and minus the standard deviation given in parentheses. For falcate conidia, the shortest distance between both ends (i.e. diameter) was measured. The specimens were deposited in the fungarium of the University of Vienna (WU).

\section{Pure culture isolation}

Mature ascomata on corticated twigs were horizontally cut using a sterile razor blade, the apothecia separated from the surrounding host tissue, transferred in a sterile drop of water on a microscope slide, torn apart with a forceps to release the ascospores from asci and pipetted on a $2 \%$ malt extract agar (MEA) plate supplemented with $200 \mathrm{mg} / \mathrm{L}$ penicillin $\mathrm{G}$ and streptomycin sulphate (Sigma-Aldrich, St. Louis, MO). Germinated ascospores were then transferred to $2 \%$ MEA plates, which were sealed with laboratory film and incubated at room temperature. Cultures were deposited at CBS-KNAW Fungal Biodiversity Centre, Utrecht, The Netherlands (CBS).

\section{DNA extraction, PCR and sequencing}

Growth of liquid cultures and extraction of genomic DNA was done according to Voglmayr and Jaklitsch (2011), either using the modified CTAB extraction protocol of Riethmüller et al. (2002) or the DNeasy Plant Mini Kit (QIAgen GmbH, Hilden, Germany). The following loci were used for identification and phylogenetic analyses: The complete ITS region and D1 and D2 domains of 28S nuc rDNA region (ITS-28S) were amplified using the primers V9G (de Hoog and de and Gerrits van den Ende 1998) and LR5 (Vilgalys and Hester 1990). The 18S nuc rDNA region was amplified with primers SL1 (Landvik et al. 1997) and NS24mod (Voglmayr and Jaklitsch 2011). A ca $1.1 \mathrm{~kb}$ fragment of the RNA polymerase II subunit 2 ( $r p b 2)$ gene was amplified using the primer pair fRPB2-5f and fRPB2-7cr (Liu et al. 1999). A ca $1.3 \mathrm{~kb}$ fragment of translation elongation factor 1- $\alpha$ (tef 1$)$ gene was amplified with the primers EF1728F (Carbone and Kohn 1999) and TEF1LLErev (Jaklitsch et al. 2005). The latter fragment includes the fourth and the fifth intron and a significant portion of the last large exon. A ca. $0.8 \mathrm{~kb}$ fragment of the $\beta$-tubulin (tub2) gene was amplified with primers T1HV (5' CANMATGCGYGAGATYGTAYGT $3^{\prime}$ ) and BtHV2r ( $5^{\prime}$ CATCATRCGRTCNGGGAACTC 3'), which were newly developed for Dothideomycetes. T1HV is a modified version of primer T1 (O'Donnell and Cigelnik 1997), whereas BtHV2r is upstream from T222 (O’Donnell and Cigelnik 1997); the primers were developed from genome sequences of representative Dothideomycetes downloaded from the Joint Genome Institute (JGI, http://jgi.doe.gov/). PCR products were purified using an enzymatic PCR cleanup (Werle et al. 1994) as described in Voglmayr and Jaklitsch (2008). DNA was cyclesequenced using the ABI PRISM Big Dye Terminator Cycle Sequencing Ready Reaction Kit v. 3.1 (Applied Biosystems, Warrington) and the PCR primers; in addition, the following primers were used: ITS-28S region: ITS4 (White et al. 1990), LR3 (Vilgalys and Hester 1990); SSU: NS1088 (Kauff and Lutzoni 2002). Sequencing was performed on an automated DNA sequencer (ABI 3730xl Genetic Analyzer, Applied Biosystems).

\section{Phylogenetic analyses}

To reveal the phylogenetic position of the two new genera, a matrix of aligned nucleotide sequences from four different phylogenetic markers (18S, 28S, rpb2 and tef1), and 219 representatives of Dothideomycetes and Eurotiomycetes, including two species from Lecanoromycetes as outgroup, was produced. The matrix of Boehm et al. (2015) was downloaded from TreeBASE (www.treebase.org; submission No. S $16,151)$ and served as the matrix basis after removal of a few sequences. Sequences of six additional taxa were downloaded from the GenBank nucleotide database. These, together with the newly generated sequences, were manually aligned to the matrix of Boehm et al. (2015), or realigned with the server version of MAFFT (www.ebi.ac.uk/Tools/mafft). The resulting alignments were subsequently checked and refined using BioEdit version v. 7.0.4.1 (Hall 1999). For alignment of $r p b 2$, first the alignment of Boehm et al. (2015) was translated into a protein matrix which was then re-aligned with the new protein sequences using MAFFT, and the respective new DNA sequences were then manually aligned to the original $r p b 2$ nucleotide matrix using the protein alignment as reference. Prior to phylogenetic analyses, the approach of Wiens (1998) was applied to test for significant levels of localized incongruence among the four genes, using the level of bootstrap support (Sung et al. 2007). For this, the $80 \%$ 
maximum likelihood (ML) bootstrap consensus trees for each individual partition were compared using the same parameters as for the combined analysis given below, but using 100 fast bootstrap replicates. No significant topological conflicts were observed between the bootstrap trees of $18 \mathrm{~S}, 28 \mathrm{~S}, r p b 2$ and tef 1 , indicating the absence of significant incongruence and combinability of the matrices (Wiens 1998). The resulting combined sequence matrix contained 5721 nucleotide positions from four genes (1653 from 18S, 1230 from 28S, 1875 from $r p b 2,963$ from tef1). GenBank accession numbers of newly generated sequences are given in Table 1 .

For detailed phylogenetic analyses within the new family, the ITS-28S, $r p b 2$ and $t u b 2$ sequences of all accessions sequenced were aligned and combined in a single three-loci matrix; for GenBank accession numbers see Table 1. This three-loci matrix contained $3657 \mathrm{nu}-$ cleotide positions (1654 from ITS-28S, 1168 from $r p b 2$ and 835 from tub2).

For maximum likelihood (ML) analyses and Bayesian inference (BI) of the multi-gene analysis of Dothideomycetes, unique model parameters were applied for each marker and codon (where applicable), with the dataset divided in eight partitions according to Schoch et al. (2009a). The general time reversible model, assuming a proportion of invariant sites and gammadistributed substitution rates $(\mathrm{GTR}+\mathrm{I}+\mathrm{G})$, was selected as best model for all four genes (LSU, SSU, $r p b 2$ and tef1) by Modeltest 3.6 (Posada and Crandall 1998) under the Akaike Information Criterion (AIC) and was implemented in the subsequent ML and BI analyses. The matrix of Stigmatodiscaceae was divided in three partitions according to the three loci.

For ML analyses, fast tree searches were done with RAxML (Stamatakis 2006) as implemented in raxmlGUI 1.3 (Silvestro and Michalak 2012), using the GTRGAMMAI substitution model. 500 fast bootstrap replicates were computed using the GTRCATI substitution model.

Bayesian analyses were performed on the large matrix of Dothideomycetes with the computer program MrBayes (version 3.2.2; Huelsenbeck and Ronquist 2001). Three parallel runs of four incrementally heated, simultaneous Markov chains were performed over 10 million generations, of which every 1000th tree was sampled in each run, using the GTR + $\mathrm{I}+\mathrm{G}$ model for all eight partitions. The first 4000 of the 10 , 000 trees sampled were discarded, and a $90 \%$ majority rule consensus of the remaining trees was computed to obtain posterior probabilities (PP).

Maximum parsimony (MP) analyses were performed with PAUP v. 4.0a142 (Swofford 2002) only for the small threeloci matrix of Stigmatodiscaceae, using 1000 replicates of heuristic search with random addition of sequences and subsequent TBR branch swapping (MULTREES option in effect,

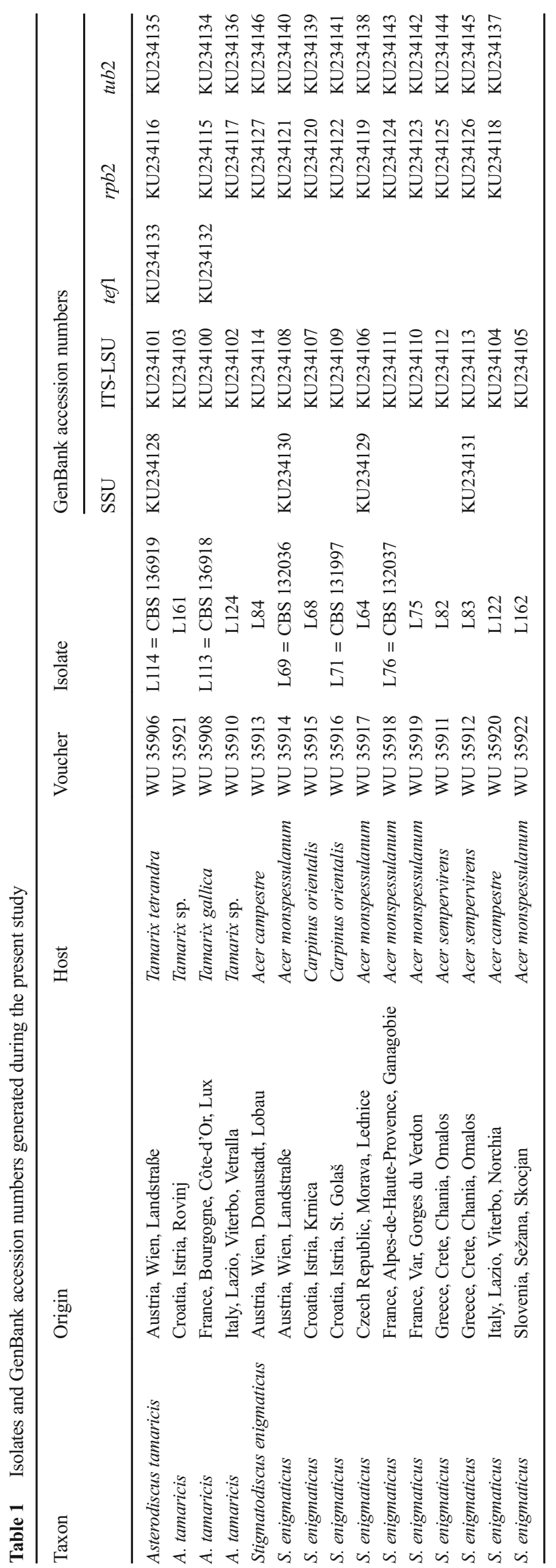


steepest descent option not in effect). All molecular characters were unordered and given equal weight; analyses were performed with gaps treated as missing data; the COLLAPSE command was set to NO. Bootstrap analysis with 1000 replicates was performed in the same way, but using 10 rounds of random sequence addition and subsequent TBR branch swapping during each bootstrap replicate.

\section{Results}

\section{Molecular phylogeny}

No tefl sequences could be obtained for Stigmatodiscus, despite various attempts using different primer sets, polymerases or PCR protocols; therefore, this gene could only be included

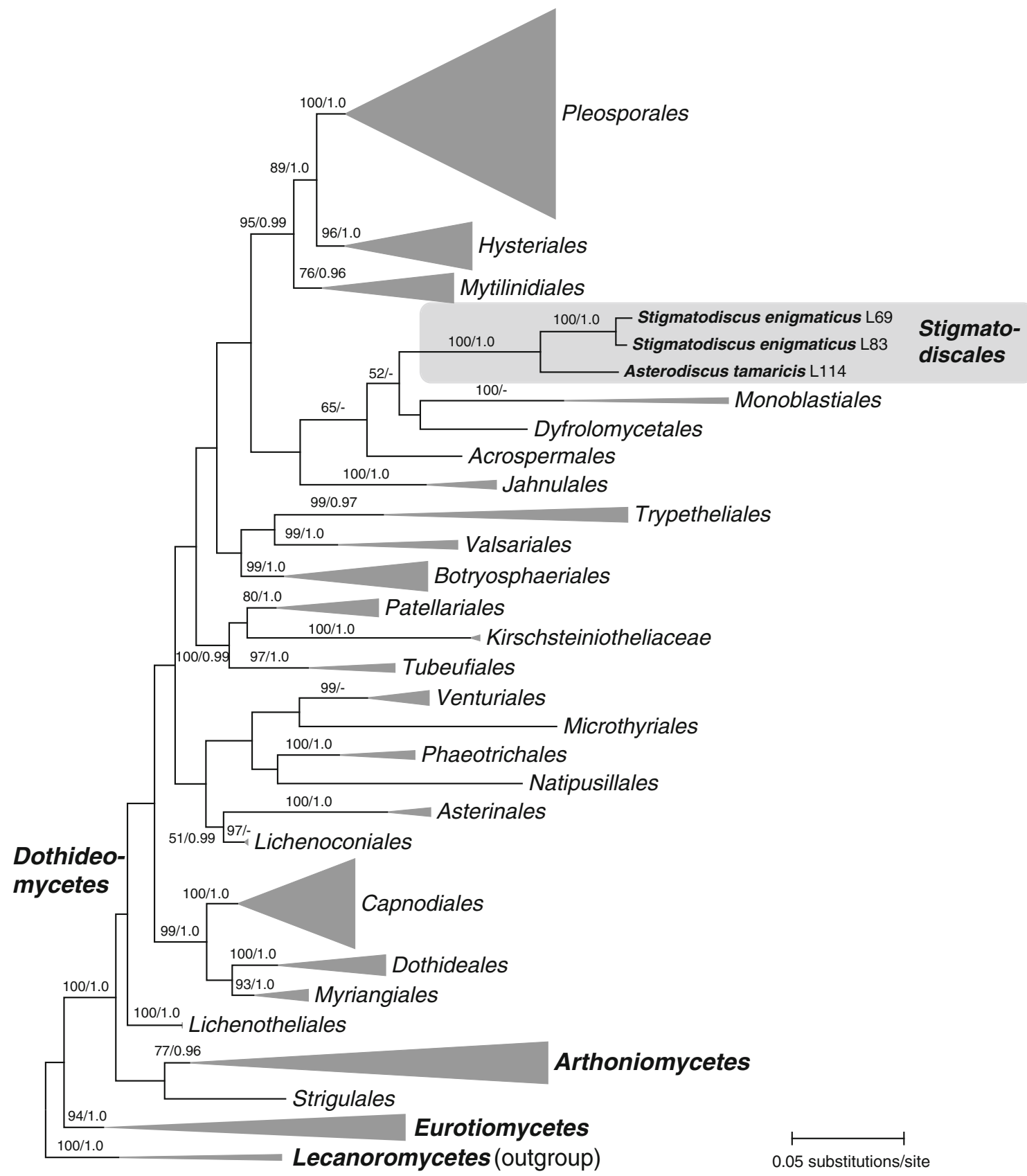

Fig. 1 Simplified phylogram showing the best RAxML maximum likelihood tree $(\operatorname{lnL}=-137,324.200031)$ obtained from the combined multigene (LSU, SSU, rpb2, tef1) matrix of 219 taxa including major orders in Dothideomycetes, Arthoniomycetes and Eurotiomycetes, with two members of Lecanoromycetes (Cladonia caroliniana, Flavoparmelia caperata) selected as outgroup according to Boehm et al. (2015). Ordinal and familial classification follows
Hyde et al. (2013) and Boehm et al. (2015). Stigmatodiscus and Asterodiscus form a highly supported clade representing a distinct order within Dothideomycetes. Except for Stigmatodiscales, all lineages were collapsed to ordinal or familial level. ML bootstrap support above $50 \%$ and Bayesian posterior probabilities above 0.9 are given above or below the branches 
for Asterodiscus in the multi-gene analyses of Dothideomycetes. Of the 5721 nucleotide positions included in the Dothideomycetes matrix, 2595 were parsimony informative (488 from 18S, 507 from 28S, 1198 from $r p b 2,402$ from tef 1 ). The best ML tree revealed by the RAxML analysis of the matrix including representatives of all major orders and families of Dothideomycetes, Arthoniales, Trypetheliales and Eurotiomycetes is shown as phylogram in Fig. 1, with the orders/families collapsed to enable a better overview. As observed in previous studies on Dothideomycetes (e.g. Schoch et al. 2009a, 2009b, Hyde et al. 2013; Wijayawardene et al. 2014; Boehm et al. 2015), many of the deeper nodes receive insignificant or low internal support, whereas many of the orders and families are highly supported. Asterodiscus and Stigmatodiscus form a distinct highly supported clade within Dothideomycetes and are contained in a clade with Monoblastiales, Dyfrolomycetales and Acrospermales, but only with low ML bootstrap support $(65 \%)$. Sister group relationship of the Asterodiscus-Stigmatodiscus clade to the Monoblastiales-Dyfrolomycetales clade receives low ML bootstrap support as well (52\%), which means that a statistically well-supported close relationship to other orders within Dothideomycetes remains obscure at this time.

Of the 5721 nucleotide positions included in the three-loci matrix of Stigmatodiscaceae, 476 were parsimony informative (148 from 28S-ITS, 208 from $r p b 2,120$ from $t u b 2$ ). The MP analysis revealed 12 MP trees of score 580; in the strict consensus tree, all nodes lacking MP bootstrap support collapsed to a polytomy (data not shown). Figure 2 shows the best ML tree of the detailed phylogenetic analysis of Stigmatodiscaceae revealed by RAxML, which is fully compatible with the MP strict consensus tree. Within Stigmatodiscus enigmaticus, some sequence variability was observed between the various accessions included in the analyses. The accessions from Crete on Acer sempervirens were set apart as sister group to the other accessions with moderate (ML) to high (MP) support. There is no further grouping according to hosts or geographic origins, and the lack of morphological differentiation indicates that only a single
Stigmatodiscus species is involved. The sequences of all three Asterodiscus accessions from Austria, France and Italy were highly similar to identical.

\section{Taxonomy}

Stigmatodiscales Voglmayr \& Jaklitsch, ord. nov. MycoBank MB 815325.

Type family: Stigmatodiscaceae Voglmayr \& Jaklitsch.

Ascomata apothecioid, embedded in cortex of dead twigs, without distinct margin nor excipulum. Hamathecium paraphysate; paraphyses septate, unbranched or rarely branched and anastomosing above, with free apical ends, covered by an epithecium. Asci bitunicate, fissitunicate, I-, without a ring. Ascospores large, slightly to strongly asymmetric, hyaline to brown, multiseptate with one euseptum and several distosepta, wall surrounded by gel coating. Conidiomata in nature immersed, peridermal, pycnidial.

Stigmatodiscaceae Voglmayr \& Jaklitsch, fam. nov.

MycoBank MB 815326.

Type genus: Stigmatodiscus Voglmayr \& Jaklitsch.

Ascomata apothecioid, embedded in cortex of dead twigs, dark brown to black, without distinct margin. Hamathecium paraphysate; paraphyses septate, unbranched or rarely branched and anastomosing above, with swollen free apical ends, embedded in a rubber-like gel matrix and covered by an epithecium. Hymenial gel I-. Asci sequentially produced over a long time, bitunicate, fissitunicate, I-, broadly fusoid to saccate, with thin ecto- and thick endotunica, apically with wide ocular chamber, without a ring. Ascospores slightly to strongly asymmetric, distal part larger than proximal part, hyaline to brown, 1-euseptate in early stages, developing 2 additional distosepta, wall surrounded by gel coating. Conidiomata in nature immersed, peridermal, pycnidial.

Asterodiscus Voglmayr, Gardiennet \& Jaklitsch, gen. nov. MycoBank MB 815329, Facesoffungi number: FoF 01656.

Etymology: Referring to the striking similarity of its ascospores to those of Asteromassaria.
Fig. 2 Phylogram the of best RAxML maximum likelihood tree $(\operatorname{lnL}=-7783.3102)$ obtained from the combined multigene matrix of ITS-LSU, $r p b 2$ and tub2 from Asterodiscus and Stigmatodiscus. ML and MP bootstrap values above $50 \%$ are given above or below the branches

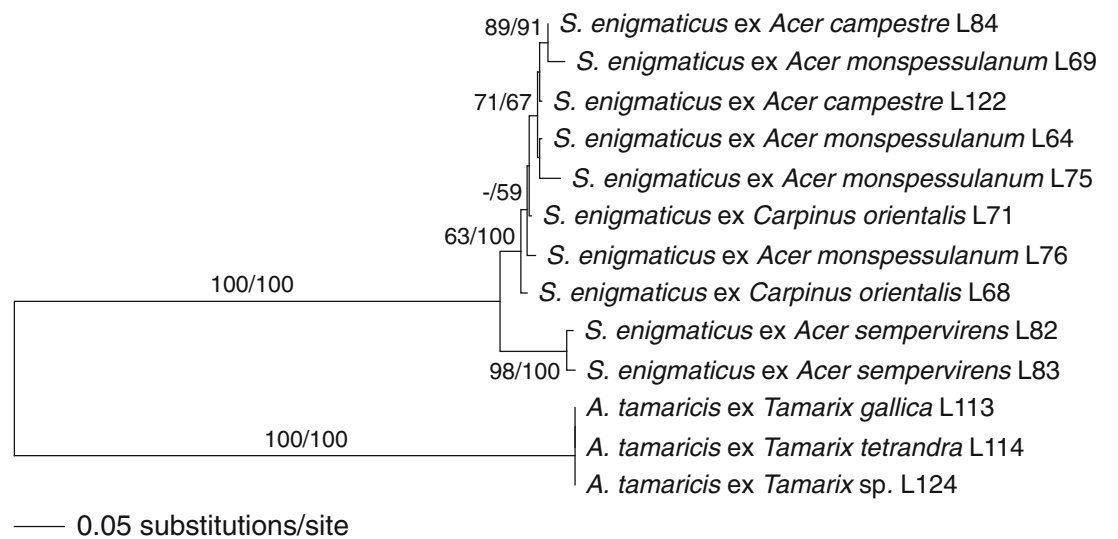


Type species: Asterodiscus tamaricis Voglmayr, Gardiennet \& Jaklitsch.

Ascomata embedded in cortex of dead twigs, initially covered by bark, lifting the bark as a black bump, globosedepressed to broadly pyriform, apically covered by black tissue of textura intricata, at maturity apothecioid, breaking open in the centre with irregular radial cracks; finally a depressed disc becoming fully exposed with age, sometimes confluent with neighbouring discs, dark brown to black, without distinct margin. Hamathecium of hyaline, septate paraphyses, often branched and anastomosing above, with distinctly swollen free apical ends, embedded in a rubber-like gel matrix and covered by an amorphous matrix forming an epithecium. Hymenial gel I-. Asci forming sequentially and slowly, bitunicate, fissitunicate, I-, variable in shape from broadly fusoid to saccate, with thin ecto- and thick endotunica; apex with a wide ocular chamber, without ring. Ascospores large, 30-50 $\mu \mathrm{m}$ long, asymmetric, distal part slightly larger than the proximal part, ends rounded to subacute, hyaline to light brown with age, first 1-euseptate, developing 2 additional distosepta and becoming 3-septate, distinctly constricted at the septa, secondary septa with large pores; wall thick, smooth to slightly verruculose, surrounded by gel coating widely expanding in water after spore discharge; lumina ellipsoidrectangular in mid cells, semiglobose in end cells. Asexual morph in pure culture acervular, superficial, aggregated, conidiogenous cells phialidic, conidia thread-like, sinuously curved to allantoid.

Asterodiscus tamaricis Voglmayr, Gardiennet \& Jaklitsch, sp. nov.

MycoBank MB 815330, Facesoffungi number: FoF 01657, Figs. 3, 4.

Etymology: Referring to its occurrence on Tamarix spp.

Ascomata apothecioid, embedded in cortex of dead twigs, initially covered by bark, emerging as a black bump 130$200 \mu \mathrm{m}$ diam when young, later upper layer breaking open in the centre with irregular radial cracks, finally a circular to elongated flat to depressed, 200-600 $\mu \mathrm{m}$ wide disc becoming fully exposed, sometimes confluent with neighbouring discs, dark brown to black, without distinct margin. Subhymenium thin, ca 15-20 $\mu \mathrm{m}$ thick, brown, of tightly packed subhyaline to light brown hyphae 3-8 $\mu \mathrm{m}$ diam. Paraphyses 80-150 $\mu \mathrm{m}$ long, 2$3.5 \mu \mathrm{m}$ wide, hyaline, septate, cells sometimes becoming inflated up to $7 \mu \mathrm{m}$ with age, with free apical ends swollen, club-like, up to $9 \mu \mathrm{m}$ wide, apical swellings with age incrusted by a deep blue, finely granular stain, covered by an olivaceous, emerald to deep blue amorphous incrustation. Hymenial gel in lower part hyaline, in upper part dark olivaceous, emerald to deep blue. Asci (73-)96-144(-163) × (35-)42-59(-72) $\mu \mathrm{m}$ $(n=26)$, variable in shape from broadly fusoid to saccate, thick-walled, containing 8 irregularly bi- to triseriate ascospores. Ascospores (33.4-)39.8$45(-48.8) \times(12.8-) 14.3-16.5(-17.7) \mu \mathrm{m}, 1 /$ $\mathrm{w}=(2.4-) 2.6-2.9(-3.2)(n=90)$, asymmetric, first 1septate, developing 2 additional distosepta and becoming 3-septate with age, strongly constricted at the primary septum, weakly at secondary septa, secondary septa with large pores, hyaline to light brown with age, becoming dark brown after ejection, ends mostly rounded, distal ends sometimes subacute, surrounded by a thick gelatinous sheath, wall smooth to finely verruculose, the contents granular, with a large, strongly refractive guttule per cell.

Conidiomata on the natural substrate not observed, on $2 \%$ MEA acervular, superficial, aggregated, ca 200-450 $\mu \mathrm{m}$ wide, conidiophores densely aggregated, branched. Conidiogenous cells phialidic, (7.2-)10.2-15.3(-20.4) $\times(1.8-) 2.1-3.2(-3.8)$ $\mu \mathrm{m}(n=30)$, lageniform. Conidia irregularly sinuously curved to falcate, $(9.4-) 10.6-13.6(-17.4) \times(1.0-) 1.2-1.6(-2.1) \mu \mathrm{m}$ $(n=70)$, hyaline, smooth. Cultures very slow-growing, with uneven margins, colony on $2 \%$ MEA reaching $32 \mathrm{~mm}$ diam after one month at room temperature, first whitish, turning dark brown, with whitish aerial hyphae in the centre, reverse first hazelnut brown, then black; on PDA colony light brown, cottony, with the centre covered by whitish mycelium, reverse hazelnut brown with dark brown centre.

Holotype: AUSTRIA, Wien, Landstraße, Botanical Garden of the University (HBV), on Tamarix tetrandra, 1 Aug 2013, H. Voglmayr (WU 35906, ex-type culture CBS $136919=\mathrm{L} 114)$.

Additional specimens examined: AUSTRIA, Wien, Landstraße, Botanical Garden of the University (HBV), on Tamarix tetrandra, 7 May 2015, H. Voglmayr (WU 35924). CROATIA, Istria, Rovinj, Kamp Amarin, on Tamarix sp., 15 May 2015, H. Voglmayr, M. \& I. Greilhuber (WU 35921, culture L161). FRANCE, Bourgogne, Côte-d'Or (21), Issur-Tille, route de Dijon, on Tamarix gallica, 25 Apr 2015, A. Gardiennet AG15034 (WU 35907). Lux, on Tamarix gallica, 21 Jul 2013, R. Rousseaux \& A. Gardiennet AG13137 (WU 35908, culture L113 = CBS 136918). Véronnes, on Tamarix gallica, 16 Apr 2015, A. Gardiennet AG15029 (WU 35909). ITALY, Lazio, Viterbo, Vetralla, on

Fig. 3 Asterodiscus tamaricis, sexual morph. a, b Ascomata erumpent from bark in face view. c Ascomata in transverse section, showing the hymenium with asci. $\mathbf{d}-\mathbf{h}$ Vertical sections of ascomata embedded in bark; d, e closed young ascomata showing the hamathecial threads connected with apical dark brown tissue of textura intricata; $\mathbf{f}-\mathbf{h}$ apothecioid ascomata with paraphyses and asci embedded in a gel matrix stained bluish (f, g) to olivaceous (h) below the epithecium. $\mathbf{i}, \mathbf{j}$ Olivaceous to dark brown epithecium of young ascomata forming a textura intricata and young paraphyses below; (i) detail from d. All in water. Sources: $a, c, h$. WU 35908; $b$. WU 35907; $d-g, i, j$. WU 35924. Scale bars: $a=1 \mathrm{~mm} . b=250 \mu \mathrm{m} . c=100 \mu \mathrm{m} . d-h=50 \mu \mathrm{m} . i, j=10 \mu \mathrm{m}$ 

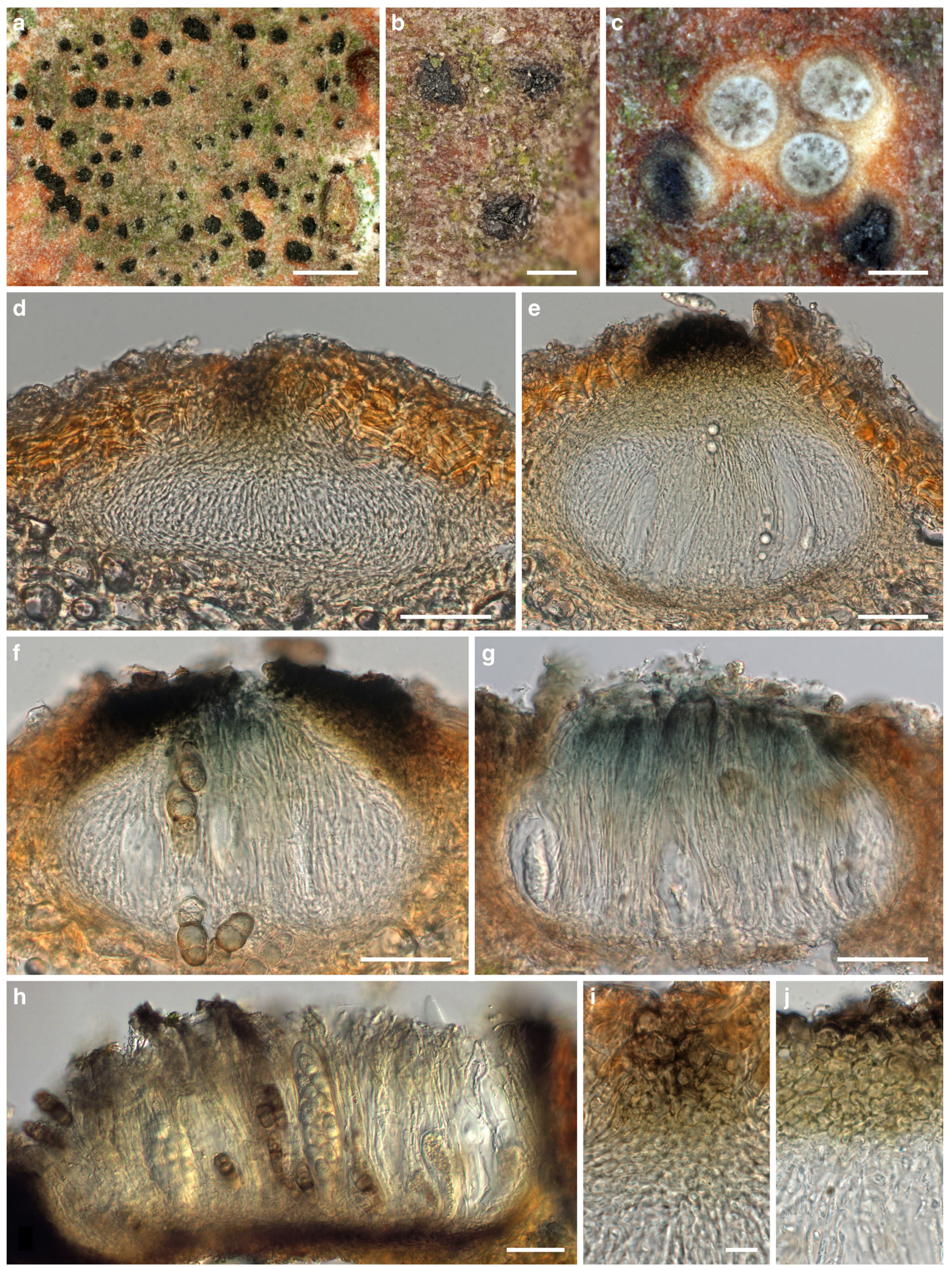
Tamarix sp., 14 Oct 2013, W. Jaklitsch, H. Voglmayr \& W. Gams (WU 35910, culture L124).

Stigmatodiscus Voglmayr \& Jaklitsch, gen. nov.

MycoBank MB 815327, Facesoffungi number: FoF 01654.

Etymology: Referring to the striking similarity of its ascospores to those of Stigmatomassaria.

Type species: Stigmatodiscus enigmaticus Voglmayr \& Jaklitsch.

Ascomata apothecioid, embedded in cortex of dead twigs, initially covered by bark, later becoming exposed through irregular cracks, eventually becoming fully exposed with age, dark brown to black, without distinct margin. Hamathecium of hyaline, septate paraphyses, unbranched or rarely branched and anastomosing above, with distinctly swollen free apical ends, embedded in a rubber-like gel matrix and covered by an amorphous matrix forming an epithecium. Hymenial gel I-. Asci sequentially produced over a long time, bitunicate, fissitunicate, I-, variable in shape from broadly fusoid to saccate, with thin ecto- and thick endotunica, apically with wide ocular chamber, without ring. Ascospores large, 45-80 $\mu \mathrm{m}$ long, asymmetric, distal part distinctly larger than the proximal part, proximal end rounded, distal end rounded to subacute, brown, 1-euseptate in early stages, developing 2 additional distosepta and becoming 3- septate, distinctly constricted at the septa, secondary septa with large pores; wall thick, punctate to verruculose, surrounded by gel coating widely expanding in water after spore discharge; lumina ellipsoid in mid cells, ellipsoid to conoid in end cells. Conidiomata on natural substrates immersed, peridermal, pycnidial, thinwalled, on $2 \%$ MEA superficial, acervular, condiogenous cells phialidic, conidia falcate.

Stigmatodiscus enigmaticus Voglmayr \& Jaklitsch, sp. nov.

MycoBank MB 815328, Facesoffungi number: FoF 01655, Figs. 5, 6.

Etymology: Referring to the uncertainties in classification when first observed.

Ascomata apothecioid, embedded in cortex of dead twigs, initially covered by bark, emerging through irregular cracks, eventually becoming fully exposed, dark brown to black, variable in size, 0.4-1.5 mm diam, without distinct margin. Subhymenium thin, ca 25-30 $\mu \mathrm{m}$ thick, of tightly packed hyaline, 3-8 $\mu \mathrm{m}$ wide hyphae. Paraphyses 180-300 $\mu \mathrm{m}$ long, 3-5.5 $\mu \mathrm{m}$ wide, free apical ends swollen up to $9 \mu \mathrm{m}$, covered by a dark brown amorphous incrustation. Asci (124-)152$205(-257) \times(46-) 54-73(-81) \mu \mathrm{m}(n=33)$, variable in shape from broadly fusoid to saccate, thick-walled, containing 8 irregularly bi- to triseriate ascospores. Ascospores $(45.8-) 54.2-64.2(-73) \times(16.5-) 20.0-24.3(-32.5) \mu \mathrm{m}, \mathrm{l} /$ $\mathrm{w}=(2.2-) 2.5-2.9(-3.6)(n=228)$, brown, asymmetric, first 1 -septate, developing 2 additional distosepta and becoming 3 septate with age, constricted at the septa, surrounded by a
Fig. 4 Asterodiscus tamaricis, sexual $(\mathbf{a}-\mathbf{q})$ and asexual $(\mathbf{r}-\mathbf{v})$ morph. ad Apically inflated septate paraphyses, covered by an olivaceous $(\mathbf{a}, \mathbf{b})$ to deep blue (c, d) amorphous incrustation. e Subhymenium and bases of paraphyses. f, $\mathbf{g}$ Asci, in $\mathbf{g}$ embedded in gel matrix with paraphyses. $\mathbf{h}-\mathbf{k}$ Hyaline ascospores. $\mathbf{l}-\mathbf{q}$ Brown ascospores after ejection; in $\mathbf{p}$ showing verruculose wall ornamentation, in $\mathbf{q}$ showing gel sheath. $\mathbf{r}, \mathbf{s}$ Acervular conidiomata on MEA showing conidial drops. $\mathbf{t}$, $\mathbf{u}$ Phialides on branched conidiophores. v Conidia. All in water; $\mathbf{q}$ in black ink. Sources: $a, c, d$. WU $35908, b, e, g, m-q$. WU 35924; $f, i-l$. WU 35907; $h$. WU 35906 (holotype); $r-v$. WU 35921. Scale bars: $a, b, d=5 \mu \mathrm{m} . c, e, h-q, r-$ $v=10 \mu \mathrm{m} . f, g=20 \mu \mathrm{m} . r=400 \mu \mathrm{m} . s=200 \mu \mathrm{m}$

thick gelatinous sheath, wall distinctly verruculose, dark brown, the contents granular, often with a large and several smaller guttules per cell.

Conidiomata on the natural substrate associated with ascomata, immersed, peridermal, pycnidial, depressed, unilocular, of circular to irregular shape, opening in irregular bark cracks, 200-500 $\mu \mathrm{m}$ diam, wall thin, inconspicuous, ca. 10$15 \mu \mathrm{m}$, composed of hyaline cells. Ostiole dark brown. Condiogenous cells phialidic, cylindrical, (11.2-)13.0$17.3(-21.7) \times(1.5-) 2.0-3.0(-3.7) \mu \mathrm{m}(n=40)$. Conidia falcate, $(9.3-) 13.0-17.0(-18.7) \times(1.0-) 1.3-1.7(-2.0) \mu \mathrm{m}$ $(n=99)$, not germinating on $2 \%$ MEA. On $2 \%$ MEA forming superficial, aggregated, 250-400 $\mu \mathrm{m}$ wide acervuli, conidiogenous cells and conidia similar to those on the natural substrate. Conidiophores branched. Conidiogenous cells

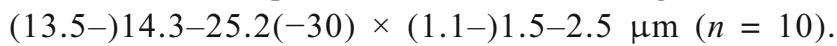
Conidia (9.0-)12.7-19.7(-24.2) × (1.0-)1.1-1.5(-1.8) $(n=40)$. Cultures on $2 \%$ MEA very slow-growing, reaching $14 \mathrm{~mm}$ diam after one month at room temperature, dark grey to black, at age with whitish aerial hyphae in the centre, reverse first brown, then black.

Holotype: AUSTRIA, Wien, Landstraße, Botanical Garden of the University (HBV), on Acer monspessulanum, 14 Oct. 2010, H. Voglmayr (WU 35914, ex-type culture CBS 132036 = L69).

Additional specimens examined: AUSTRIA, Niederösterreich, Gumpoldskirchen, near Richardshof, on Acer campestre, 24 May 2015, H. Voglmayr \& I. Greilhuber (WU 35931). Wien, Donaustadt, Lobau, Panozzalacke, on Acer campestre, 4 Feb. 2012, H. Voglmayr (WU 35913, culture L84). Landstraße, Botanical Garden of the University (HBV), on Acer monspessulanum, 7 May 2015, H. Voglmayr (WU 35925). CROATIA, Istria, Krnica, on Carpinus orientalis, 25 Sep. 2010, H. Voglmayr \& W. Jaklitsch (WU 35915, culture L68). St. Golaš, on Carpinus orientalis, 31 Oct 2010, H. Voglmayr (WU 35916, culture L71 = CBS 131997). CZECH REPUBLIC, Morava, Lednice, Arboretum, on Acer monspessulanum, 9 Oct 2010, H. Voglmayr \& W. Jaklitsch (WU 35917, culture L64). FRANCE, Provence-Alpes-Côte d'Azur, Dept. Alpes-deHaute-Provence (04), Prieuré de Ganagobie, on Acer monspessulanum, 30 Jul 2011, H. Voglmayr (WU 35918, 

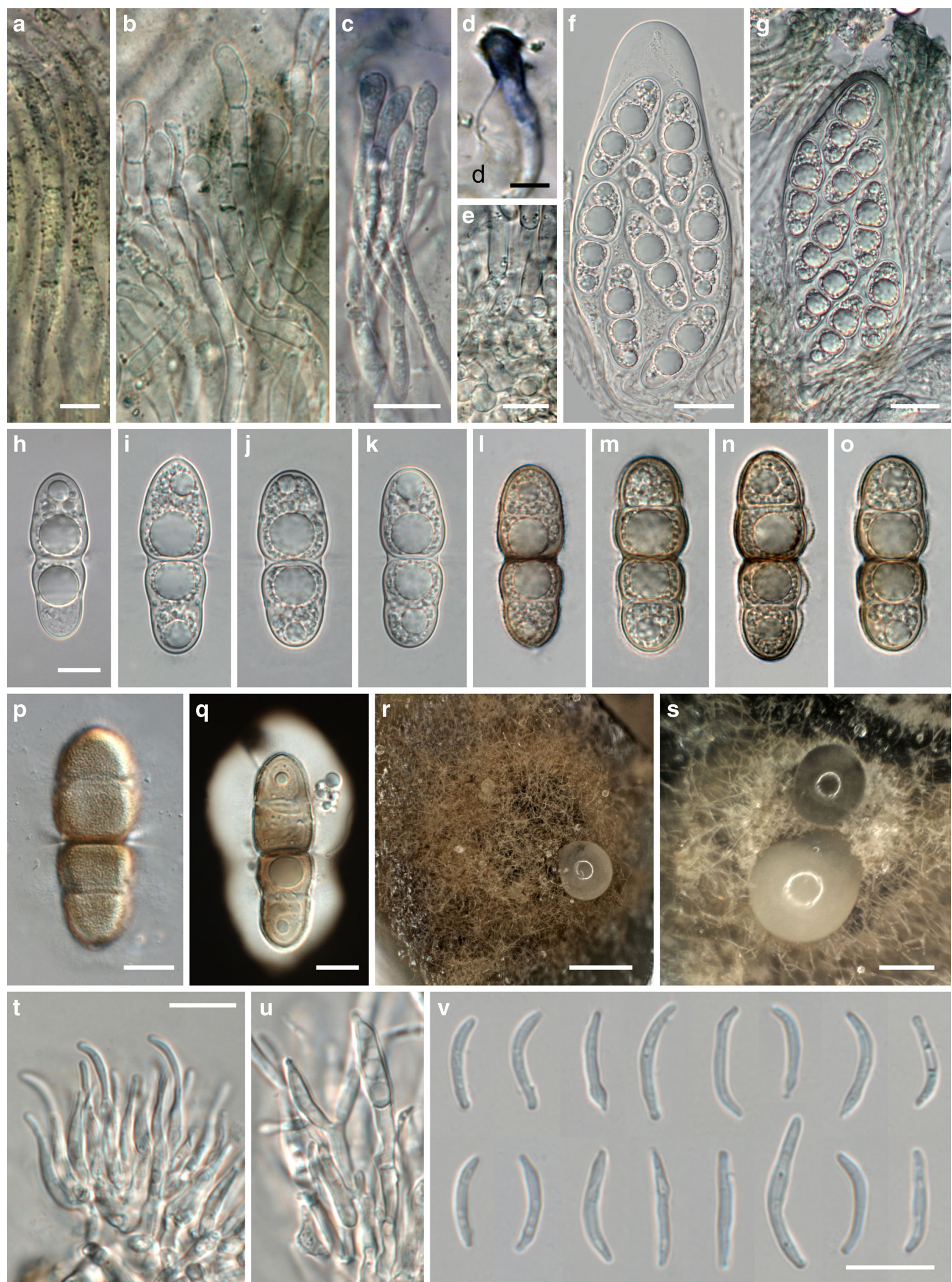

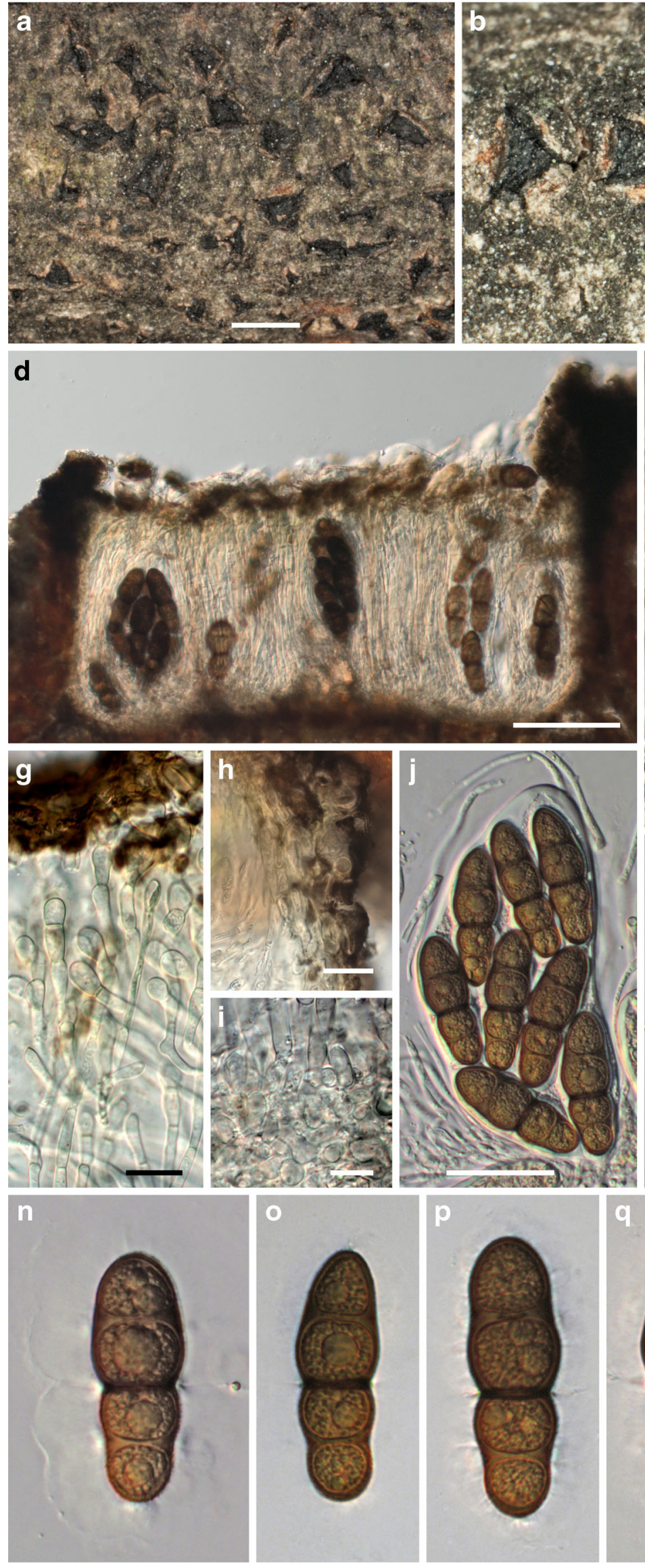

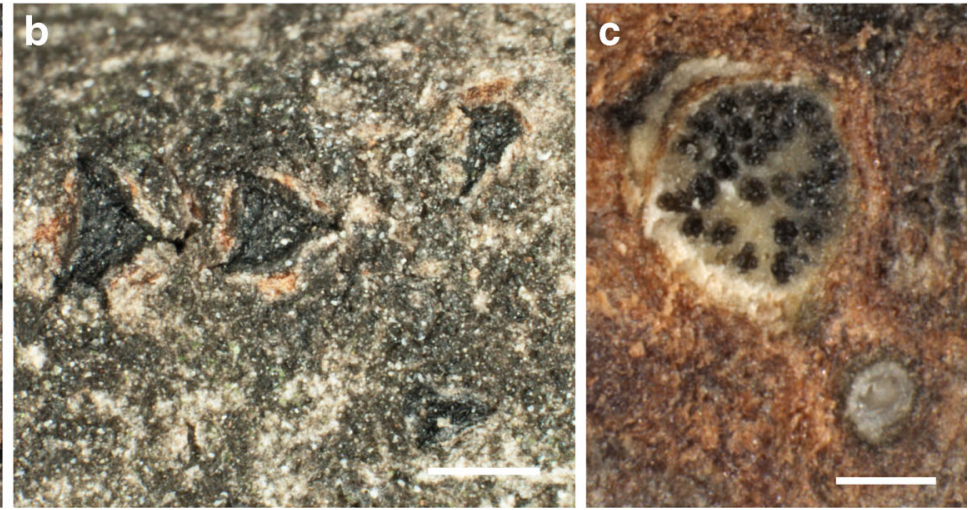

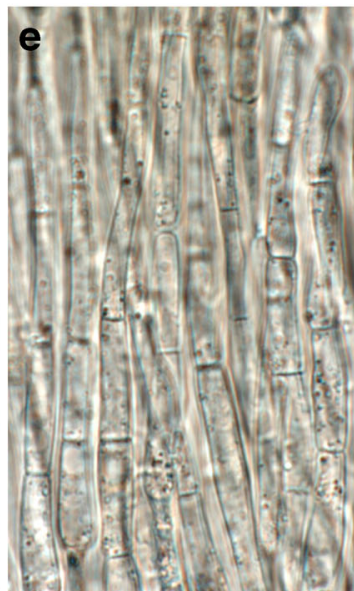

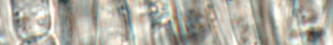

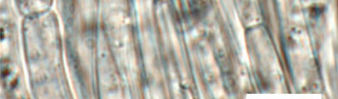

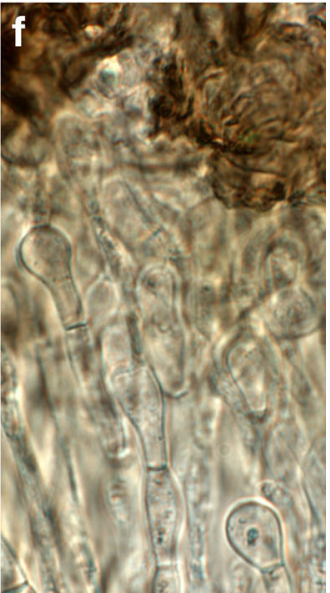
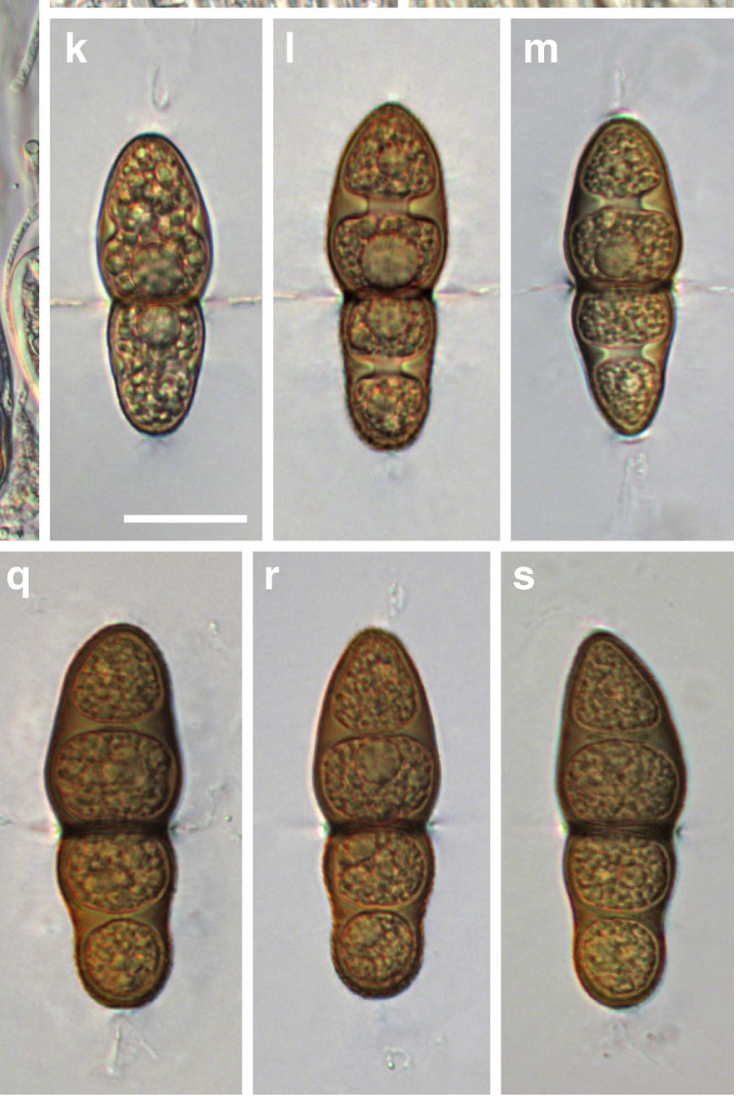
4 Fig. 5 Stigmatodiscus enigmaticus, sexual morph. a, b Ascomata erumpent from bark in face view. c Ascoma and pycnidium (bottom right) in transverse section, showing the hymenium with asci. d Vertical section of apothecioid ascomata embedded in bark, showing the paraphyses and asci embedded in a gel matrix stained dark olivaceous brown below the dark brown epithecium. e-g Septate, apically inflated (f, g) paraphyses, covered by a dark brown epithecium (f, g). h Dark brown cells of apothecium margins. i Subhymenium and bases of paraphyses. $\mathbf{j}$ Ascus. $\mathbf{k}-\mathbf{s}$ Ascospores; $\mathbf{k}-\mathbf{m}$ immature showing the central euseptum and the developing additional distosepta, $\mathbf{n}-\mathbf{s}$ mature, in $\mathbf{n}$ showing gel sheath. All in water. Sources: $a, b, j, o-s$. WU 35914 (holotype); $c, g, i$. WU $35925 ; d-f, h$. WU $35931 ; k, l$. WU $35917 ; m$. WU $35915 ; n$. WU 35913. Scale bars: $a=1 \mathrm{~mm} . b=500 \mu \mathrm{m} . c=200 \mu \mathrm{m} . d=100 \mu \mathrm{m} . e$, $f, i=10 \mu \mathrm{m} . g, h=20 \mu \mathrm{m} . j=50 \mu \mathrm{m} . k-S=20 \mu \mathrm{m}$

culture L76 = CBS 132037). Dept. Var (83), Gorges du Verdon, Pont de l'Artuby, on Acer monspessulanum, $28 \mathrm{Jul}$ 2011, H. Voglmayr (WU 35919, culture L75). GREECE, Crete, Chania, Omalos, $920 \mathrm{~m}, 35.37^{\circ} \mathrm{N}, 23.897^{\circ} \mathrm{E}$, on Acer sempervirens, 26 Nov 2011, W. Jaklitsch (WU 35911, culture L82). ibid., 5 June 2015, H. Voglmayr \& W. Jaklitsch (WU 35932). Omalos, $1040 \mathrm{~m}, 35.362^{\circ} \mathrm{N}, 23.908^{\circ} \mathrm{E}$, on Acer sempervirens, 28 Nov 2011, W. Jaklitsch (WU 35912, culture L83). ibid., 5 June 2015, H. Voglmayr \& W. Jaklitsch (WU 35933). Chania, Askifou, E Karés, 790 m, 35.296 ${ }^{\circ}$ N, 24.209 E, on Acer sempervirens, 6 June 2015, H. Voglmayr \& W. Jaklitsch (WU 35934). ENE Karés, $670 \mathrm{~m}, 35.305^{\circ} \mathrm{N}$, $24.204^{\circ} \mathrm{E}$, on Acer sempervirens, 6 June 2015, H. Voglmayr $\&$ W. Jaklitsch (WU 35935). Rhetimno, Psiloritis, S Anogia, $930 \mathrm{~m}, 35.274^{\circ} \mathrm{N}, 24.886^{\circ} \mathrm{E}$, on Acer sempervirens, 8 June 2015, H. Voglmayr \& W. Jaklitsch (WU 35936). Psiloritis, S Anogia, $1490 \mathrm{~m}, 35.22^{\circ} \mathrm{N}, 24.87^{\circ} \mathrm{E}$, on Acer sempervirens, 8 June 2015, H. Voglmayr \& W. Jaklitsch (WU 35937). ITALY, Lazio, Viterbo, Norchia, on Acer campestre, 14 Oct 2013, H. Voglmayr, W. Jaklitsch \& W. Gams (WU 35920, culture L122). Montalto di Castro, Vulci, on Acer monspessulanum, 15 Oct 2013, H. Voglmayr, W. Jaklitsch \& W. Gams (WU 35923 ). SloveniA, Sežana, Skocjan, on Acer monspessulanum, 17 May 2015, H. Voglmayr \& I. Greilhuber (WU 35922, culture L162).

Notes: The sequences of the collections from Acer sempervirens in Crete deviate slightly from the other collections; however, morphological features match the species. The variability is therefore considered to be within the intraspecific range of the species and may be the result of genetic isolation on a Mediterranean island.

\section{Discussion}

Phylogenetic analyses place Stigmatodiscales within Dothideomycetes (Fig. 1), but their closest relatives remain obscure and unresolved. A weakly support relationship to Monoblastiales, Dyfrolomycetales and Acrospermales is only revealed in $\mathrm{ML}$ analyses, and these orders are morphologically and ecologically highly distinct (Hyde et al. 2013; Pang et al. 2013).

Morphologically, the two new genera share a unique combination of characters within Dothideomycetes: they have apothecial ascomata embedded in host tissue lacking an excipulum, saccate fissitunicate asci, large, 3-septate ascospores with an excentric euseptum and two additional distosepta, being surrounded by a large gelatinous sheath. Ascospores of Stigmatodiscus resemble those of Stigmatomassaria and are to our knowledge unknown in other groups of Dothideomycetes. Some species of Lichenothelia have brown asymmetric ascospores with one euseptum and two distosepta surrounded by a large gelatinous sheath (Hawksworth 1981). However, the ascomata of Lichenothelia are quite unlike those of Stigmatodiscales; they are superficial and perithecioid when young, becoming apothecioid (lecideine) at maturity with an excipulum composed of pseudoparenchymatous tissue (Hawksworth 1981; Øvstedal and Lewis Smith 2001). In addition, in Lichenothelia species with 3-septate ascospores these are much smaller (less than $30 \mu \mathrm{m}$ long) and commonly become submuriform by additional transverse septa (Hawksworth 1981; Henssen 1987). Ecologically, Lichenothelia differs by inhabiting rocks, being often found in association with algae or with lichen thalli (Øvstedal and Lewis Smith 2001; Muggia et al. 2012). Ascospores similar to those of Asterodiscus can be also found in other groups, particularly in the Arthopyreniaceae of the Pleosporales, but ascomata of members of this family do not open to become apothecial (Hyde et al. 2013). Within Trypetheliaceae, Architrypethelium and Ornatopyrenis have similar ascospores of the same size as observed in Stigmatodiscales, but they are lichenized and pyrenocarpous (Aptroot 1991). In Xylopezia (Sherwood-Pike and Boise 1986), where ascomata are first immersed and closed, asci are functionally unitunicate and the ascospores are euseptate. The only order of the Dothideomycetes comprising exclusively discomycetous fungi is the Patellariales. However, all representatives of this order form black, droughttolerant, more or less superficial apothecia, and their ascospores are euseptate, except in Lirellodisca (Kutorga and Hawksworth 1997; Yacharoen et al. 2015). All lineages discussed above for which sequence data are available are phylogenetically distant from Stigmatodiscales (Fig. 1).

Although ascospores of the Stigmatodiscales are highly similar to those of the genera Asteromassaria and Stigmatomassaria, the fungi of the present study are phylogenetically remote from these. Asteromassaria and Stigmatomassaria are both contained within Pleomassariaceae, Pleosporales (unpubl. data), whereas the fungi of the present study form a highly supported clade within Dothideomycetes, which is of uncertain phylogenetic affinity (Fig. 1). In addition, ascomata of Asteromassaria and Stigmatomassaria are perithecioid pseudothecia typical of 

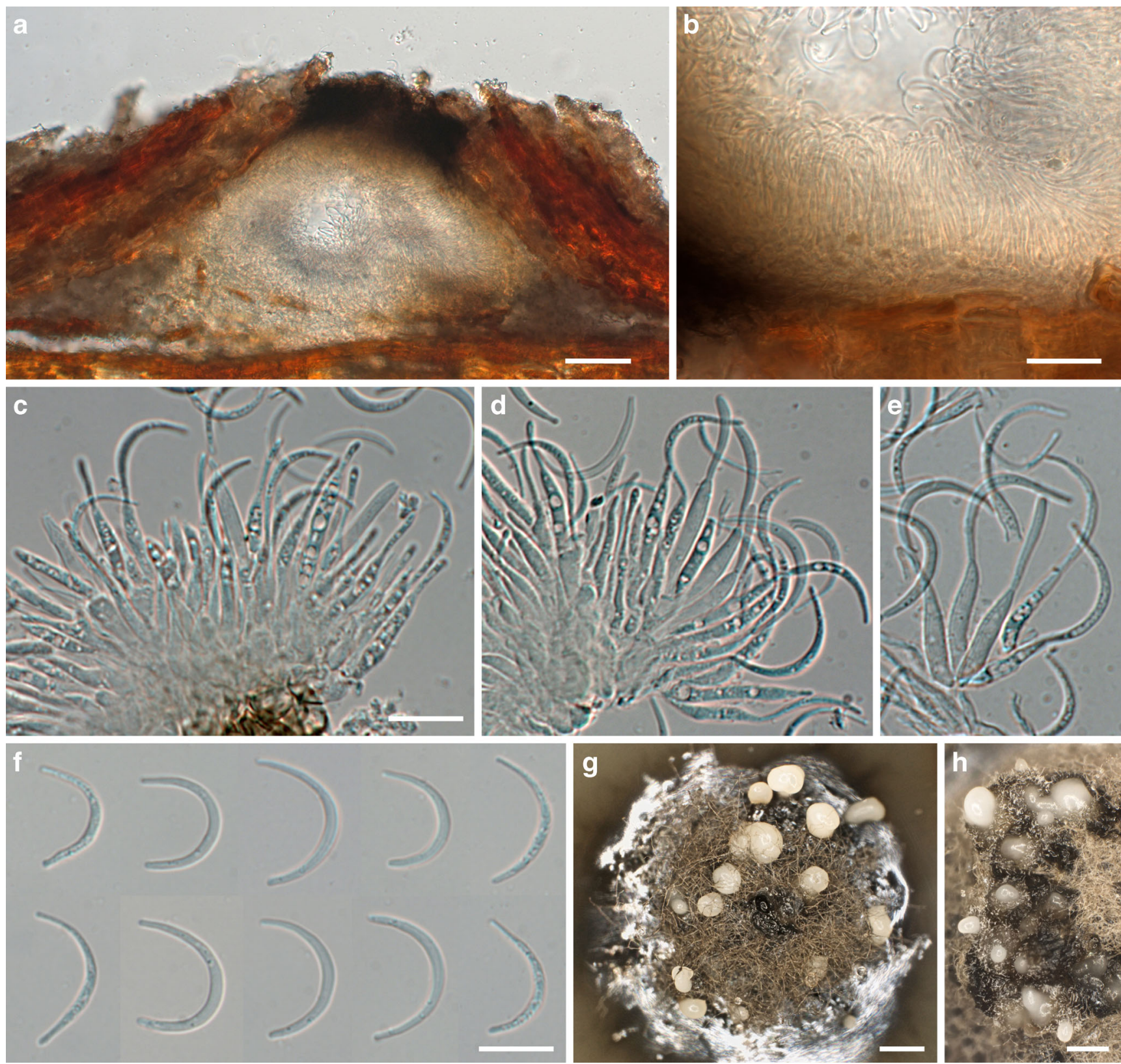

Fig. 6 Stigmatodiscus enigmaticus, asexual morph. a Conidioma (pycnidium) immersed in periderm. b Detail of pycnidium with densely aggregated conidiogenous cells and conidia. c-e Phialides producing

conidia. $\mathbf{f}$ Falcate conidia. $\mathbf{g}, \mathbf{h}$ Acervular conidiomata on MEA showing conidial drops. All in water. Sources: $c, d, f-g$. WU 35922; $a, b, e$. WU 35925. Scale bars: $a=100 \mu \mathrm{m} . b=20 \mu \mathrm{m} . c-f=10 \mu \mathrm{m} . g, h=400 \mu \mathrm{m}$

Pleomassariaceae (Barr 1982). Acknowledging their profound phylogenetic and morphological distinctness, classification within two new genera in a new family and order is fully justified.

The genera Asterodiscus and Stigmatodiscus are similar in their ascomatal traits. The main differences concern the ascospore shape and colouration, analogous to the closely related genera Asteromassaria and Stigmatomassaria. Asterodiscus has hyaline, only slightly asymmetric ascospores which become brownish only after ejection, whereas Stigmatodiscus has dark brown, asymmetric ascospores with the distal part distinctly larger than the proximal part.

Ecologically, species of Asterodiscus and Stigmatodiscus are characterised by growth on recently dead corticated twigs still attached to the trees. While Asterodiscus appears to be confined to Tamarix spp., Stigmatodiscus has been primarily observed on various Acer species (A. campestre, A. monspessulanum, A. sempervirens) but also on the unrelated Carpinus orientalis. Asterodiscus tamaricis and Stigmatodiscus enigmaticus are widely distributed in Central and Southern Europe and have been commonly observed 
during the current study on various Tamarix spp. and Acer monspessulanum, respectively. Occurrence on exposed twigs primarily in submediterranean climate indicates a high level of drought tolerance. It is remarkable that they have remained undetected up to date on these widely distributed hosts, demonstrating once again the need of detailed biodiversity studies on corticolous ascomycetes especially in Central and Southern Europe (e.g. Voglmayr and Jaklitsch 2008, 2011, 2014; Jaklitsch and Voglmayr 2011, 2014; Voglmayr et al. 2012; Jaklitsch et al. 2013, 2014, 2015; Galán et al. 2015; Checa et al. 2015).

Acknowledgments The financial support by the Austrian Science Fund (FWF; project P25870-B16) to WJ is gratefully acknowledged. We thank Conrad Schoch for providing the matrix of Dothideomycetes, Irmgard Greilhuber and Walter Gams for excursion support and especially R. Rousseaux for collection of AG13137. Hans-Otto Baral and Robert Lücking are gratefully acknowledged for providing their expertise on apothecioid Dothideomycetes.

Open Access This article is distributed under the terms of the Creative Commons Attribution 4.0 International License (http:// creativecommons.org/licenses/by/4.0/), which permits unrestricted use, distribution, and reproduction in any medium, provided you give appropriate credit to the original author(s) and the source, provide a link to the Creative Commons license, and indicate if changes were made.

\section{References}

Aptroot A (1991) A monograph of the Pyrenulaceae (excluding Anthracothecium and Pyrenula) and the Requiennellaceae, with notes on the Pleomassariaceae, the Trypetheliaceae and Mycomicrothelia (lichenized and non-lichenized ascomycetes). Bibliotheca Lichenol 44:1-178

Barr ME (1982) On the Pleomassariaceae (Pleosporales) in North America. Mycotaxon 15:349-383

Boehm EW, Marson G, Mathiassen GH, Gardiennet A, Schoch CL (2015) An overview of the genus Glyphium and its phylogenetic placement in Patellariales. Mycologia 107:607-618

Carbone I, Kohn LM (1999) A method for designing primer sets for speciation studies in filamentous ascomycetes. Mycologia 91:553-556

Checa J, Jaklitsch WM, Blanco MN, Moreno G, Tello S, Olariaga I, Voglmayr H (2015) Two new species of Thyronectria from mediteranean Europe. Additions to genus. Mycologia 107:1314 1322

de HGS, Gerrits van den Ende AHG (1998) Molecular diagnostics of clinical strains of filamentous basidiomycetes. Mycoses 41:183-189

Galán R, Checa J, Blanco MN, Platas G, Tena R, Tello S, Hermosilla CE, Jaklitsch WM, Voglmayr H (2015) Taxonomic position of the genus Bicornispora and the appearance of a new species Bicornispora seditiosa. Mycologia 107:793-807

Hall TA (1999) BioEdit: a user-friendly biological sequence alignment editor and analysis program for windows 95/98/NT. Nucleic Acids Symp Ser 41:95-98

Hawksworth DL (1981) Lichenothelia, a new genus for the Microthelia aterrima group. Lichenologist 13:141-153

Henssen A (1987) Lichenothelia, a genus of microfungi on rocks. Bibliotheca Lichenol 25:257-293
Huelsenbeck JP, Ronquist F (2001) MrBayes: Bayesian inference of phylogenetic trees. Bioinformatics 17:754-755

Hyde KD, Jones EBG, Liu JK, Ariyawansa H, Boehm E, et al. (2013) Families of Dothideomycetes. Fungal Divers 63:1-313

Jaklitsch WM, Voglmayr H (2011) Nectria eustromatica sp. nov., an exceptional species with a hypocreaceous stroma. Mycologia 103: 209-218

Jaklitsch WM, Voglmayr H (2014) Persistent hamathecial threads in the Nectriaceae, Hypocreales: Thyronectria revisited and re-instated. Persoonia 33:182-211

Jaklitsch WM, Komon M, Kubicek CP, Druzhinina IS (2005) Hypocrea voglmayrii sp. nov. from the Austrian alps represents a new phylogenetic clade in Hypocrea/Trichoderma. Mycologia 97:1365-1378

Jaklitsch WM, Réblová M, Voglmayr H (2013) Molecular systematics of Woswasia atropurpurea gen. et sp. nov. (Sordariomycetidae), a fungicolous ascomycete with globose ascospores and holoblastic conidiogenesis. Mycologia 105:476-485

Jaklitsch WM, Fournier J, Rogers JD, Voglmayr H (2014) Phylogenetic and taxonomic revision of Lopadostoma. Persoonia 32:52-82

Jaklitsch WM, Fournier J, Dai DQ, Hyde KD, Voglmayr H (2015) Valsaria and the Valsariales. Fungal Divers 73:159-202

Kauff F, Lutzoni F (2002) Phylogeny of Gyalectales and Ostropales (Ascomycota, Fungi): among and within order relationships based on nuclear ribosomal RNA small and large subunits. Mol Phyl Evol $25: 138-156$

Kutorga E, Hawksworth DL (1997) A reassessment of the genera referred to the family Patellariaceae (Ascomycota). Systema Ascomycetum $15: 1-110$

Landvik S, Egger K, Schumacher T (1997) Towards a subordinal classification of the Pezizales (Ascomycota): phylogenetic analyses of SSU rDNA sequences. Nordic J Bot 17:403-418

Liu YL, Whelen S, Hall BD (1999) Phylogenetic relationships among ascomycetes: evidence from an RNA polymerase II subunit. Mol Biol Evol 16:1799-1808

Muggia L, Gueidan C, Knudsen K, Perlmutter G, Grube M (2012) The lichen connections of black fungi. Mycopathologia 175:523-535

O’Donnell K, Cigelnik E (1997) Two divergent intragenomic rDNA ITS2 types within a monophyletic lineage of the fungus Fusarium are nonorthologous. Mol Phyl Evol 7:103-116

Øvstedal DO, Lewis Smith RI (2001) Lichens of Antarctica and South Georgia: a guide to their identification and ecology. Cambridge University Press, Cambridge, Studies in Polar Research, 411 pp

Pang KL, Hyde KD, Alias SA, Suetrong S, Guo SY, Idid R, Jones EBG (2013) Dyfrolomycetaceae, a new family in the Dothideomycetes, Ascomycota. Cryptogamie Mycol 34:223-232

Posada D, Crandall KA (1998) Modeltest: testing the model of DNA substitution. Bioinformatics 14:817-818

Riethmüller A, Voglmayr H, Göker M, Weiß M, Oberwinkler F (2002) Phylogenetic relationships of the downy mildews (Peronosporales) and related groups based on nuclear large subunit ribosomal DNA sequences. Mycologia 94:834-849

Schoch CL, Sung GH, Lopez-Giraldez F, Townsend JP, Miadlikowska J, et al. (2009a) The Ascomycota tree of life: a phylum-wide phylogeny clarifies the origin and evolution of fundamental reproductive and ecological traits. Syst Biol 58:224-239

Schoch CL, Crous PW, Groenewald JZ, Boehm EW, Burgess TI, et al. (2009b) A class-wide phylogenetic assessment of Dothideomycetes. Stud Mycol 64:1-15

Sherwood-Pike MA, Boise JR (1986) Studies in lignicolous ascomycetes: Xylopezia and Mycowinteria. Brittonia 38:35-44

Silvestro D, Michalak I (2012) RaxmlGUI: a graphical front-end for RAxML. Org Divers Evol 12:335-337 
Stamatakis E (2006) RAxML-VI-HPC: maximum likelihood-based phylogenetic analyses with thousands of taxa and mixed models. Bioinformatics 22:2688-2690

Sung GH, Sung JM, Hywel-Jones NL, Spatafora JW (2007) A multigene phylogeny of Clavicipitaceae (Ascomycota, Fungi): identification of localized incongruence using a combinational bootstrap approach. Mol Phyl Evol 44:1204-1223

Swofford DL (2002) PAUP* 4.0b10: phylogenetic analysis using parsimony (*and other methods). Sinauer Associates, Sunderland, Massachusetts

Vilgalys R, Hester M (1990) Rapid genetic identification and mapping of enzymatically amplified ribosomal DNA from several Cryptococcus species. J Bacteriol 172:4238-4246

Voglmayr H, Jaklitsch WM (2008) Prosthecium species with Stegonsporium anamorphs on Acer. Mycol Res 112:885-905

Voglmayr H, Jaklitsch WM (2011) Molecular data reveal high host specificity in the phylogenetically isolated genus Massaria (Ascomycota, Massariaceae). Fungal Divers 46:133-170

Voglmayr H, Jaklitsch WM (2014) Stilbosporaceae resurrected: generic reclassification and speciation. Persoonia 33:61-82
Voglmayr H, Rossman AY, Castlebury LA, Jaklitsch W (2012) Multigene phylogeny and taxonomy of the genus Melanconiella (Diaporthales). Fungal Divers 57:1-44

Werle E, Schneider C, Renner M, Völker M, Fiehn W (1994) Convenient single-step, one tube purification of PCR products for direct sequencing. Nucleic Acids Res 22:4354-4355

White TJ, Bruns T, Lee S, Taylor J (1990) Amplification and direct sequencing of fungal ribosomal RNA genes for phylogenies. In: Innis MA, Gelfand DH, Sninsky JJ, White TJ (eds) PCR protocols: a guide to methods and applications. Academic Press, San Diego, pp. 315322

Wiens JJ (1998) Combining datasets with different phylogenetic histories. Syst Biol 47:568-581

Wijayawardene NN, Crous PW, Kirk PM, Hawksworth DL, Boonmee S, et al. (2014) Naming and outline of Dothideomycetes-2014 including proposals for the protection or suppression of generic names. Fungal Divers 69:1-55

Yacharoen S, Tian Q, Chomnunti P, Boonmee S, Chukeatirote E, Bhat JD, Hyde KD (2015) Patellariaceae revisited. Mycosphere 6:290 326 